\title{
ANTHROPOMETRIC PARAMETERS OF FIRST-YEAR STUDENTS OF PEDAGOGICAL SPECIALTIES
}

\section{Svetlana Vasilyeva, Inna Stepanenko, Ekaterina Kravchuk}

The topic is relevant due to a detailed study of the factors determining the health level of nowadays students, and taking these factors into consideration for the development of programs to strengthen their health. Since the scientific literary data on the physical development of student youth is somewhat contradictory, namely the morphological and functional indicators of a person depends on the level of physical health and adaptive capacity, it has been decided to determine the freshmen's anthropometric parameters.

The aim of the study was to take anthropometric measurements of total and comprehensive body size of 105 students studying at Vinnytsia Mykhailo Kotsiubynskyi State Pedagogical University, assess their compliance with anthropometric standards, determine the somatotype and foot shape in order to create a database for further monitoring of physical development and identify patterns of anthropometric indicators under conditions of modern learning technologies.

Research methods. Anthropometric measurements were taken according to standard anthropometric methods suggested by V. V. Bunak [1]. Data estimation was performed by the method of centile intervals and indices. The foot shape was assessed by the plantogram based on the Chyzhyn index. The obtained data were statistically processed according to the STATISTICA 5.5 program.

Research results. The peculiarities of anthropometric parameters and somatotype of Vinnytsia Mykhailo Kotsiubynskyi State Pedagogical University first-year students are established: height, body weight; girth sizes: chest, waist, hips; body mass index, Kettle mass-growth index, body harmony indices, foot shape

Keywords: body length and mass, girth sizes of the body, body mass index (BMI), anthropometric measurements, somatotype

How to Cite:

Vasilyeva, S., Stepanenko, I., Kravchuk, E. (2021). Anthropometric parameters of first-year students of pedagogical specialties. ScienceRise: Pedagogical Education, 2 (41), 23-26. doi: http://doi.org/10.15587/2519-4984.2021.228222

(C) The Author(s) 2021

This is an open access article under the CC BY license (http://creativecommons.org/licenses/by/4.0).

\section{Introduction}

Analysis of anthropometric parameters is an important factor in assessing the health status of students of all ages. Constant monitoring of anthropometric indicators allows to notice changes in time and, using special methods, correct the identified deviations. The main task of using the anthropometry method in a higher educational institution is to establish some indicators of the physical development of students.

Physical development together with morbidity, fertility, mortality are the leading indicators of sanitary statistics and testify to the social well-being of the population. Physical development is assessed by the state of morphological and functional properties and qualities that underlie the determination of age characteristics, physical strength and endurance of the body, and the level of biological age.

\section{Literature review}

Analysis of recent studies and publications indicates that the results of previous studies of somatometric indicators of physical development of modern youth are somewhat contradictory. Some authors note a tendency towards an increase in the number of boys and girls with asthenic physique [2]. Based on a comparison of anthropometric parameters and adaptive capabilities of modern young men and women with their peers in the 1920s1990s, they concluded that an epochal trend towards an increase in body length and deterioration of strength indicators, as well as a slight increase in body weight in modern young men [3]. Other researchers note that the anthropometric indicators of today's youth correspond to average standards [4]. The average statistical parameters of the total and girth sizes of the body of boys and girls of 16-20 years old, urban residents of the Podolsk region of Ukraine have been established [5]. In the literature there are a number of works in which the indicators of physical development of young people in different regions of different age groups were studied, depending on gender and somatotype [6].

It is noted that the intensity of mass-growth processes is influenced by the conditions of the educational process. Thus, students of a medical university with a high level of pedagogical load and a lower level of physical exertion were found to have moderate changes in partial sizes, an increase in the skin-fatty component and a decrease in the muscle component of body weight (changes in harmony indices) during training in the I-III courses [7].

Considering all of the above, it was decided to conduct research on the anthropometric parameters of first-year students at the Vinnytsia Mykhailo Kotsiubyn- 
skyi State Pedagogical University and create a database for further monitoring the physical development and somatic health of students.

\section{The aim and objectives of research}

The aim of research se of the study is to study the level of physical development of students of the Vinnytsia Mykhailo Kotsiubynskyi State Pedagogical University.

To achieve the aim, the following objectives were set:

1. Improve methods for assessing physical development, physical fitness, health level of first-year students and modernize the average statistical anthropometric standards.

2. Assess the anthropometric status of a typical modern student, future teacher.

3. Carry out activities to improve health, increase functional reserves and adaptability, improve physical and mental performance.

\section{Materials and methods}

We conducted a survey of 105 first-year students of various specialties, with the exception of students of the Institute of Physical Education and Sports at the age from 17 to 20 years old, including 32 boys and 73 girls.

The research was carried out for the last 3 years, from 2017 to 2020. All surveyed students gave their voluntary consent to participate in the study. Anthropometric measurements were carried out according to standard methods [1]. Body length was assessed using the centile interval method [8]. Correspondence of body weight to height was determined using body mass index (BMI),
Quetelet's mass-growth index. The coefficient of proportionality of the body and chest (Erisman index) was calculated. To determine the shape of the foot, plantograms were evaluated with the calculation of the Chyzhyn index.

The data obtained were statistically processed using the STATISTICA 5.5 program using the Student's t-test.

\section{Research results}

Average indicators of body length (height) in the surveyed boys are $175.08 \pm 5.24$; for girls - 165.25 \pm 5.1 . These indicators in all growth groups, both for boys and girls, exceed the centile intervals, that is, all the surveyed students have a height above the average. The average body mass indicators for boys are $68.08 \pm 1.75 \mathrm{~kg}$, for girls $-56.996 \pm 1.03 \mathrm{~kg}$ (Table 1).

The proportionality coefficient of the body in the surveyed both sexes is within the normal range: in boys from $87 \%$ to $92 \%$, and in girls - slightly lower - from $87 \%$ to $89 \%$.

According to the Quetelet's index, it was determined that 7 students ( $22 \%$ ) have normal weight, 15 $(48 \%)$ underweight, and $10(30 \%)$ overweight. In the group of girls surveyed, according to this index, normal weight was determined in 27 people (37\%), underweight - in $24(33 \%)$, overweight - in $22(30 \%)$.

According to informative unified BMI, it was determined that 17 boys $(53 \%)$ and 55 girls $(75 \%)$ have normal weight, 7 boys $(22 \%)$ and 13 girls $(18 \%)$ are underweight, and overweight - in 8 boys $(26 \%)$ and 5 girls $(6 \%)$. Obesity (BMI over $30 \mathrm{~kg} / \mathrm{m}^{2}$ ) was not recorded in either boys or girls (Fig. 1).

Table 1

Average anthropometric indicators of first-year students

\begin{tabular}{|l|c|c|}
\hline \multicolumn{1}{|c|}{ Anthropometric indicators } & Boys $(n=32)$ & Girls $(n=73)$ \\
\hline Height, cm & $175.08 \pm 5.24$ & $165.25 \pm 5.1$ \\
\hline Weight, kg & $68.08 \pm 1.75$ & $56.996 \pm 1.03$ \\
\hline Chest circumference (pause), cm & $88.52 \pm 2.14$ & $84.98 \pm 0.90$ \\
\hline Waist girth, cm & $72.90 \pm 0.91$ & $70.05 \pm 1.98$ \\
\hline Hip girth, cm & $99.10 \pm 0.73$ & $97.06 \pm 2.0$ \\
\hline BMI, kg/m ${ }^{2}$ & $19.84 \pm 0.96$ & $20.72 \pm 0.33$ \\
\hline Chest proportionality index (Erisman) & $2.5 \pm 0.47$ & $0.77 \pm 0.58$ \\
\hline WG/HG & $0.80 \pm 0.02$ & $0.75 \pm 0.03$ \\
\hline
\end{tabular}

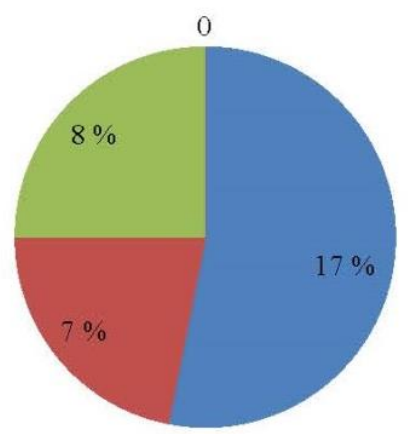

- Normal weight

- Underweight

- Overweight

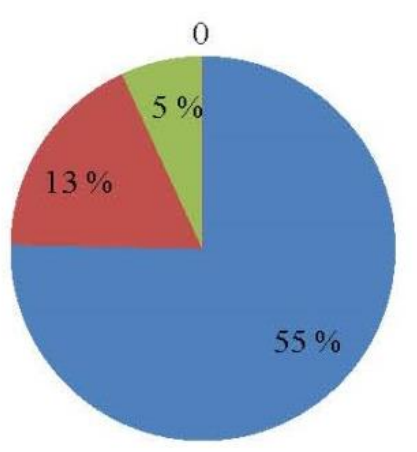

Normal weight

- Underweight

- Overweight

$a$

b

Fig. 1. Distribution of body mass index among the surveyed students: $a$-boys; $b$-girls 
At the same time, the arithmetic mean values of BMI among the surveyed students $(19.84 \pm 0.96$ - among boys; $20.72 \pm 0.33$ - among girls) correspond to the norm, and the average body mass indicators of first-year students of the VSPU in 2020 are slightly higher in comparison with the results of our previous studies conducted in $2017(p>05)[9,10]$. The maximum BMI values for boys were $28.7 \mathrm{~kg} / \mathrm{m}^{2}$, and for girls $26.9 \mathrm{~kg} / \mathrm{m}^{2} \mathrm{~g}$. As it is known, a BMI above $25 \mathrm{~kg} / \mathrm{m}^{2}$ indicates overweight and is one of the health risk factors: it leads to increased blood pressure, hyperglycemia and other adverse changes $[11,12]$.

The average indicators of weight and body length of the examined students are comparable with the results of a survey of Moscow students of the $1^{\text {st }}-2^{\text {nd }}$ year, conducted by M. Negasheva and T. Mishkova in 20022003 [3]. However, when comparing these parameters with the weight and body length of 17-year-old adolescents, one can note a significant increase in body length $(p<0.001)$ and a tendency towards a decrease in the body weight of modern girls $(p>0.05)$ [13], which confirms the opinion of some authors about asthenization as a modern epoch-making trend $[2,3]$.

The proportionality of chest development was assessed using the Erisman index. $56 \%$ of boys and $68 \%$ of girls have a narrow chest (insufficient development). The average development of the chest was determined in $44 \%$ of boys and $28 \%$ of girls, and in $4 \%$ of girls - a broad chest.

According to the data, in the last decade, there has been a significant increase in the chest index in 18-yearold boys, in contrast to girls, in whom these changes are less pronounced. Researchers note a significant increase in the chest in adolescents in Krakow in comparison with the data in 1983 and explain this fact by social changes and the level of economic development of the country [14].

To determine the somatotype (body build), the Pignet index and the Soloviev index were used. The Pignet index is considered more informative, since it takes into account a larger number of parameters of the human body: height, body weight and girth of the chest clique. This index determined that $24 \%$ of the surveyed young men have a strong body type, $22 \%$ - normal, $17 \%-$ average, $17 \%$ - weak and $17 \%$ - very weak. Among the surveyed girls, $11 \%$ have a strong body type, $22 \%-$ normal, $16 \%$ - average, $40 \%$ - weak and 11 - very weak. (Fig. 2)

According to the Soloviev index (wrist girth), it was determined that among the surveyed young men, $70 \%$ have an asthenic body type, the remaining $30 \%$ have a normosthenic type. In the group of girls surveyed, the normosthenic body type predominates; it was identified in $71 \%$ of people. $29 \%$ of female students have asthenic type.

The waist-hip index was used to assess the distribution of body fat and the body. Modern studies show that the mass of adipose tissue and its abdominal accumulation significantly affect the functional state of the cardiovascular system, increase the level of blood pressure even with normal BMI [15-19]. It has been determined that both boys (61\%) and girls (94\%) have a favorable gynoid type of fat deposition ("pear" type).The intermediate type ("avocado") was found in $39 \%$ of boys and $6 \%$ of girls, and the unfavorable android type ("apple") was not found in the surveyed students.

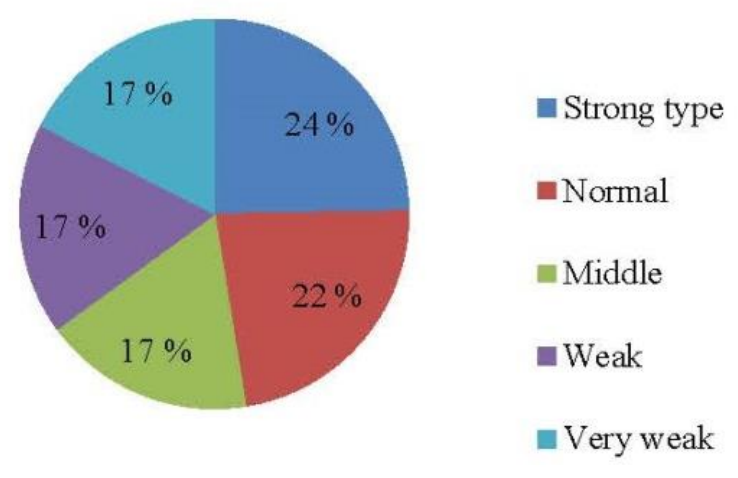

$a$

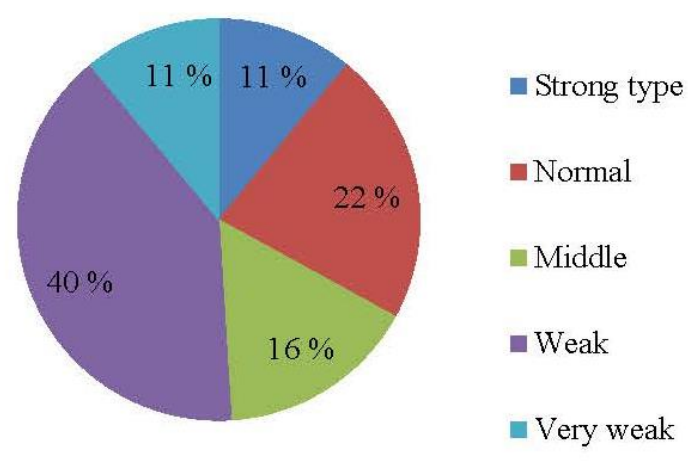

$b$

Fig. 2. Distribution of somatotypes among the surveyed students: $a$-boys; $b$-girls

The study of the shape of the foot showed that $85 \%$ of boys have a normal foot, $10 \%$ have a flat foot and $5 \%$ have a flat foot. Among girls, $57 \%$ have a normal foot, $20 \%$ have a flattened foot and $23 \%$ have a flat foot. So, $15 \%$ of boys and $43 \%$ of girls have violations of the shape of the foot (flattening or flat feet), which disrupts the functional state of muscles and joints and can cause pathological changes not only in the musculoskeletal system, but also in other functional systems.

\section{Conclusions}

1. A comprehensive study of the anthropometric status of students of different age and social groups, different specialties, living in different regions will improve the methods for assessing their physical development, physical fitness, health level and modernize the average anthropometric standards.

2. The data allow to describe the generalized anthropometric status of a typical modern student, a future teacher. This is an asthenic of high or above average height with normal or deficient body weight, with a narrow chest, with a favorable gynoid type of fatty tissue; every second has a flattened or flat foot.

3. As a result of the survey, data on the anthropometric parameters of the body of VSPU first-year students, their somatotype, the shape of the chest and feet are obtained, and on this basis a database for further monitor- 
ing of the physical development and the level of physical health of these students are created. This will strengthen their health, increase their functional reserves and adaptability, improve physical and mental performance.

\section{References}

1. Bekas, O. O. (2020). Laboratornyi praktykum z kursu vikovoi anatomii ta fiziolohii. Vinnytsia. VDPU, 148.

2. Aleksina, L. A., Rutkevich, L. A.; Aleksina, L. A. (Ed.) (2002). Progressivnye tendentsii evoliutsii cheloveka na sovremennom etape. Materialy IV Mezhdunarodnogo kongressa po integrativnoi antropologii. Saint Petersburg: Izd-vo SPb GMU, $12-13$.

3. Negasheva, M. A., Mishkova, T. A. (2005). Antropometricheskie parametry i adaptatsionnye vozmozhnosti molodezhi k nachalu XXI veka Rossiiskii pediatricheskii zhurnal, 5, 12-16.

4. Sarafyniuk, L. A., Bashynska, O., Shypitsyna, O., Kaminska, N., Sarafyniuk, O. (2008). Vikova dynamika totalnykh y obkhvatnykh rozmiriv tila v yunatskomu vitsi. Fizychna kultura, sport ta zdorovia natsii, 5, 131-133.

5. Sarafyniuk, L. A., Fomina, L. V., Kyrychenko, Yu. V., Kaminska, N. A., Kyrychenko, V. I. (2016). Determinatsiia parametriv tsentralnoi hemodynamiky antropometrychnymy predyktoramy u divchat mezoforfiv $\mathrm{z}$ riznym rivnem fizychnykh navantazhen. Visnyk problem biolohii i medytsyny, 2 (2 (129)), 301-304.

6. Must, A., Anderson, S. E. (2006). Body mass index in children and adolescents: considerations for population-based applications. International Journal of Obesity, 30 (4), 590-594. doi: http://doi.org/10.1038/sj.ijo.0803300

7. Andriichuk, V. M. (2017). Zakonomirnosti formuvannia pokaznykiv fizychnoho rozvytku yunakiv pid chas navchannia u vyshchykh navchalnykh zakladakh. Vinnytsia, 319.

8. Manueva, R. S. (2018). Fizicheskoe razvitiedetei i podrostkov. Pokazateli. Metody otsenki. Irkutsk: IGMU, 52.

9. Vasylieva, S. O., Kozak, V. V. (2018). Porivnialna kharakterystyka adaptatsiy̆nykhmozhlyvostey̆ ta antropometrychnykh parametriv shkoliariv i studentiv. Materials of XIV international research and practice conference Scientific Horizons. Science and Education Ltd Sheffield UK, 78-82.

10. Vasylieva, S. O.; Kuriaty, V. H. (Ed.) (2018). Rezultaty monitorynhu fizychnoho stanu, funktsionalnykh rezerviv ta adaptatsiynykh mozhlyvostey sertsevo-sudynnoï systemy studentiv VDPU Imeni Mykhayla Kotsiubynskoho. Suchasni problemy rozvytku biolohichnoï nauky ta metodyka ii vykladannia u zakladakh vyshchoi osvity. Vinnytsia: «Tvory», 101-110.

11. Muslov, S. A., Mkrtumian, A. M., Arutiunov, S. D. (2020). Indeks massy tela i ego sviaz s pokazateliami zdorovia u studentov MGMSU im. A.I. Evdokimova. Effektivnaia farmakoterapiia, 16 (17), 8-16.

12. Vasylieva, S. O. (2019). Vplyv nadlyshkovoi vahy na riven arterialnoho tysku i hlikemii. Aktualni problemy biolohii ta metodyky yii vykladannia u zakladakh vyshchoi osvity: zbirnyk naukovykh prats zvitnoi naukovoi konferentsii vykladachiv za 2018 - 2019 n.r. Vinnytsia, 71-81.

13. Kyrychenko, Y. V., Sarafyniuk, L. A., Sarafyniuk, P. V., Romanenko, O. I., Lischyshyn, G. B. (2019). Sexual features of spirometric indices within the juvenile period of ontogenesis. Biomedical and Biosocial Anthropology, 34, 41-46. doi: http://doi.org/10.31393/bba34-2019-06

14. Kryst, Ł., Woronkowicz, A., Kowal, M., Sobiecki, J. (2016). Intergenerational changes in chest size and proportions in children and adolescents aged 3-18 from Kraków (Poland), within the last 70 years. American Journal of Human Biology, 29 (2), e22918. doi: http://doi.org/10.1002/ajhb.22918

15. Moroz, V. M., Khapitska, O. P., Lysiuk, S. P., Kachan, V. V. (2016). Vzaiemozviazky reovazohrafichnykh parametriv homilky z antropometrychnymy rozmiramy, komponentamy somatotypu ta masy tila u bortsiv, lehkoatletiv ta voleibolistiv. Visnyk problem biolohii ta medytsyny, 2 (4 (134)), 224-229.

16. Stepanenko, I., Bekas, O. (2019). Physical Performance and Aerobic Productivity of the Body of Students with Tobacco Addiction which Have a Different Component Weight of the Body. Ukrainian Journal of Medicine, Biology and Sport, 4 (1), 249 255. doi: http://doi.org/10.26693/jmbs04.01.249

17. Bland, M. (2000). An Introduction to Medical Statistics. Oxford: Oxford University Press, 137.

18. Sarafinyuk, L. A., Khapitska, O. P., Yakusheva, Y. I., Ivanytsia, A. O., Sarafinyuk, P. V. (2018). Somatotypological features of acrobat girls in different periods of ontogenesis. Biomedical and Biosocial Anthropology, 32, 43-47. doi: http://doi.org/10.31393/bba32-2018-06

19. Shcherbin, D. V., Podskrebisheva, N. P. (2011). Tneefficiency analysis of the use of self - training for university students. Fizicheskaia reakreatsiia, 3, 63-66.

Received date 02.02.2021

Accepted date 16.03.2021

Published date 31.03.2021

Svetlana Vasilieva, PhD, Associate Professor, Department of Biology, Vinnytsia Mykhailo Kotsiubynskyi State Pedagogical University, Ostrozkoho str., 32, Vinnytsia, Ukraine, 21001

E-mail: vasylevasvetlana@gmail.com

Inna Stepanenko, Postgraduate Student, Department of Biology, Vinnytsia Mykhailo Kotsiubynskyi State Pedagogical University, Ostrozkoho str., 32, Vinnytsia, Ukraine, 21001

E-mail: innas.biologia@gmail.com

Kateryna Kravchuk, Vinnytsia Mykhailo Kotsiubynskyi State Pedagogical University, Ostrozkoho str., 32, Vinnytsia, Ukraine, 21001

Email: katerravchuk123@gmail.com 